NEW DIRECTIONS IN THEATRE

General Editor: JULIAN HILTON 


\section{NEW DIRECTIONS IN THEATRE}

\section{Published}

FEMINISM AND THEATRE

Sue-Ellen Case

IMPROVISATION IN DRAMA

Anthony Frost and Ralph Yarrow

NEW DIRECTIONS IN THEATRE

Julian Hilton

PERFORMANCE

Julian Hilton

POSTMODERNISM AND PERFORMANCE

Nick Kaye

THEATRE AS ACTION

Lars Kleberg

A SEMIOTICS OF THE DRAMATIC TEXT

Susan Melrose

TRANSPOSING DRAMA

Egil Törnqvist

Forthcoming

REPRESENTATION AND THE ACTOR

Gerry McCarthy 


\section{A Semiotics of the Dramatic Text}

SUSAN MELROSE

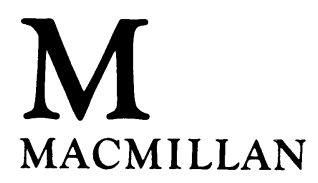


All rights reserved. No reproduction, copy or transmission of this publication may be made without written permission.

No paragraph of this publication may be reproduced, copied or transmitted save with written permission or in accordance with the provisions of the Copyright, Designs and Patents Act 1988, or under the terms of any licence permitting limited copying issued by the Copyright Licensing Agency, 90 Tottenham Court Road, London W1P 9HE.

Any person who does any unauthorised act in relation to this publication may be liable to criminal prosecution and civil claims for damages.

First published 1994 by

THE MACMILLAN PRESS LTD

Houndmills, Basingstoke, Hampshire RG21 2XS

and London

Companies and representatives

throughout the world

A catalogue record for this book is available

from the British Library.

ISBN 978-0-333-41944-1 ISBN 978-1-349-23116-4 (eBook)

DOI 10.1007/978-1-349-23116-4

Typeset by Nick Allen/Longworth Editorial Services

Longworth, Oxon. 
For Annie Ubersfeld 


\section{Contents}

General Editor's Preface viii

Acknowledgements ix

\section{PART I}

Introduction 3

1 Some Twentieth-century European Traditions Revisited 11

2 Theatre and Language 36

3 New Directions $\quad 65$

\section{PART II}

4 Interventions into the Scenes of Conflict 97

5 Old Masters 108

6 The Performer, My Other? 150

$\begin{array}{lll}7 & \text { The Gendered Scene of Theory } & 178\end{array}$

\section{PART III}

8 Exploding 'Discourse' 201

9 Procedures 245

10 Applications 283

Bibliography $\quad 315$

Index $\quad 322$ 


\section{General Editor's Preface}

In the past ten years, Theatre Studies has experienced remarkable international growth, students seeing in this marriage of the practical and the intellectual a creative and rewarding discipline. Some countries are now opening school and degree programmes in Theatre Studies for the first time; others are having to accommodate to the fact that a popular subject attracting large numbers of highly motivated students has to be given greater attention than hitherto. The professional theatre itself is changing, as graduates of degree and diploma programmes make their way through the 'fringe' into established theatre companies, film and television.

Two changes in attitudes have occurred as a result: first, that the relationship between teachers and practitioners has significantly improved, not least because many more people now have experience of both; secondly, that the widespread academic suspicion about theatre as a subject for study has at least been squarely faced, if not fully discredited. Yet there is still much to be done to translate the practical and educational achievements of the past decade into coherent theory, and this series is intended as a contribution to this task. Its contributors are chosen for their combination of professional and didactic skills, and are drawn from a wide range of countries, languages and styles in order to give some impression of the subject in its international perspective.

This series offers no single programme or ideology; yet all its authors have in common the sense of being in a period of transition and debate out of which the theory and practice of theatre cannot but emerge in a new form.

JULIAN HILTON 


\section{Acknowledgements}

My thanks to Julian Hilton for his support, to John Robinson, and to my students of theatre and drama in Tunisia, Australia and Great Britain - who continually surprise me. 